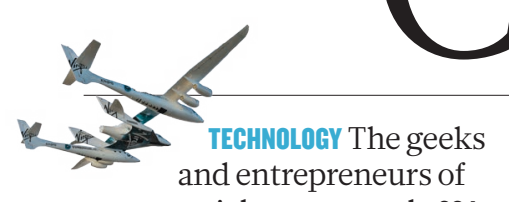

commercial space travel p.304

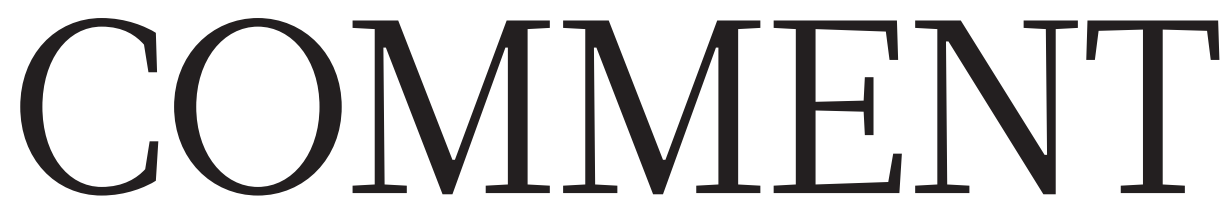

ECOLOGY Trees, a lesson in standing tall by standing together $\mathbf{p . 3 0 6}$
CHINA Sponge cities to retain run-off, control flooding, and reuse storm water $\mathbf{p . 3 0 7}$
OBITUARY Seymour Papert, father of educational computing $\mathbf{p . 3 0 8}$

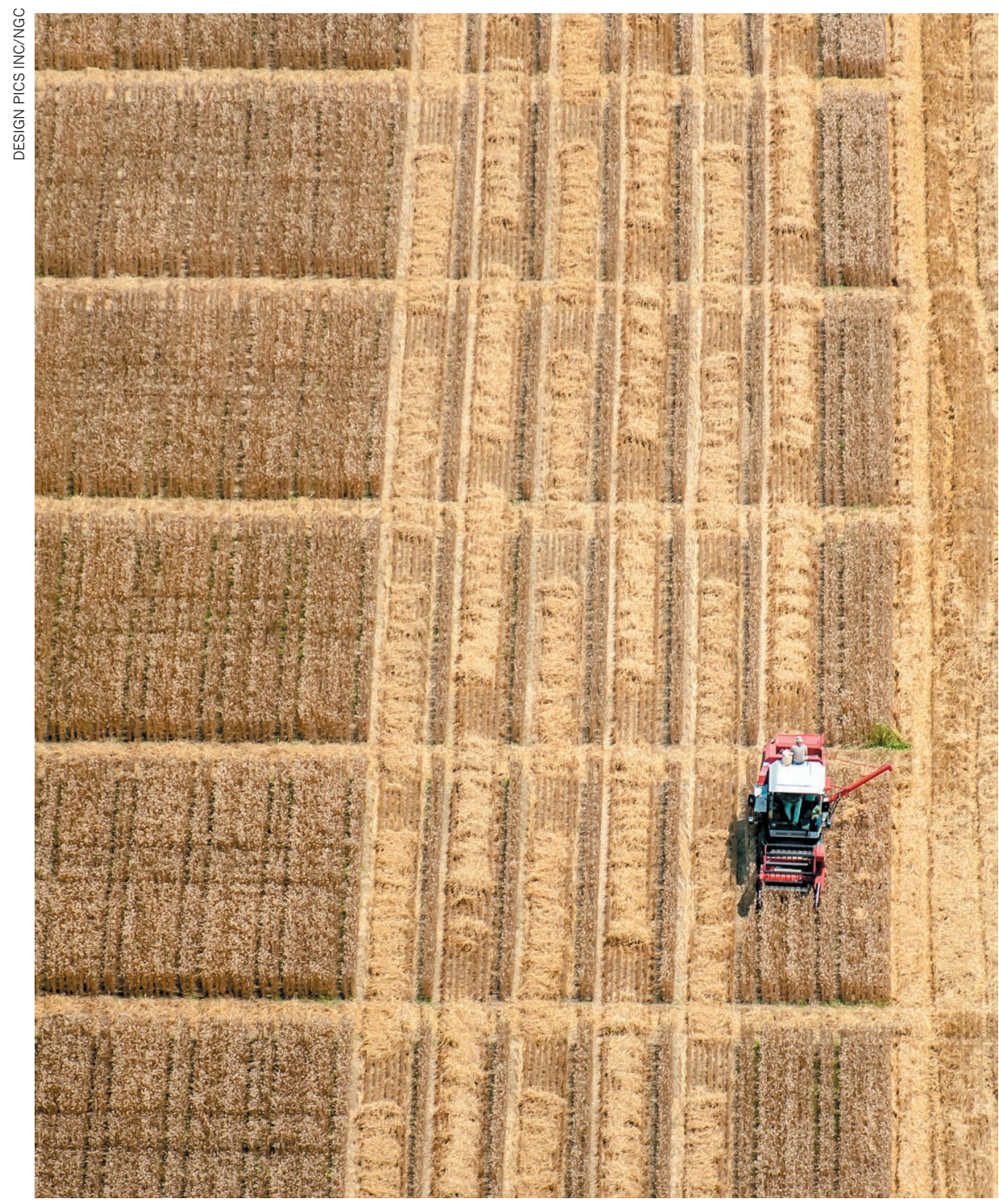

A wheat test plot in Maryland.

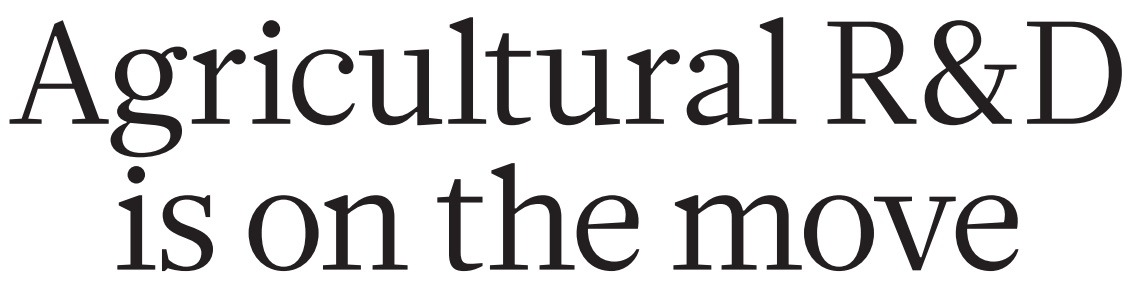

Big shifts in where research and development in food and agriculture is carried out will shape future global food production, write Philip G. Pardey and colleagues.
7 he geographical distribution of food and agricultural research and development (AgR\&D) is changing. Our analysis of more than 50 years of data indicates that the governments of middleincome nations are investing more than those of high-income ones for the first time in modern history. The numbers also suggest that, globally, private-sector spending on AgR\&D is catching up with public-sector spending. Meanwhile, the gap between spending by high-income and low-income countries is widening.

Investments in $\mathrm{R} \& \mathrm{D}$ are inextricably intertwined with growth in agricultural productivity and food supplies ${ }^{1}$. But it takes decades ${ }^{2}$, not months or years, for the consequences of these investments to be fully realized. Today's R\&D investment decisions will cast shadows forward to 2050 and beyond, making the trends we report here especially significant for the future of food production.

\section{DATA GATHERING}

To track shifts in where AgR\&D occurs worldwide, we revised and updated the various data series on spending maintained by the University of Minnesota's International Science and Technology Practice and Policy (InSTePP) Center in St Paul. Successive versions of these series have been developed over decades by collating and harmonizing data obtained from many government and international agencies, private firms and unpublished sources, and using statistical approaches developed to infer missing observations ${ }^{3}$. Our global update took 6 years, and involved direct input from more than 60 collaborators at national and international statistical and scientific agencies.

Extensive details on the construction of our data series are available online (see go.nature.com/2cc9t4b). In short, the data include new and revised estimates of the amount of AgR\&D spending by universities and government agencies for 158 countries from 1960 to 2011. They also include new global estimates of the amount of such R\&D spending by private firms for three decades, from 1980 to 2011. (All spending in local currency units was converted to international dollars using 2009 purchasing power parity (PPP) exchange rates.)

These data reveal that we are in 


\section{FEEDING THE WORLD}

More than 50 years of data show major shifts in who is spending what on food and agricultural research and development (AgR\&D). For all countries, spending in local currencies is converted to dollars using 2009 purchasing power parity (PPP) exchange rates.

Low income Middle income High income

\section{SHIFTING RANKS}

For the first time in modern history, middle-income countries are investing more in public-sector AgR\&D than are high-income ones.

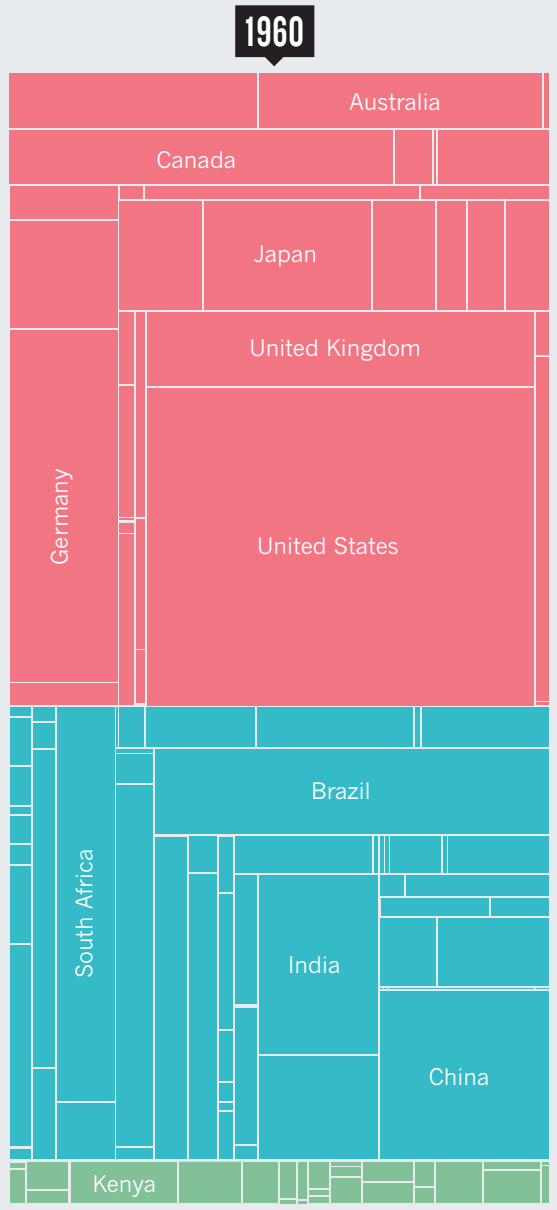

Total spend $\$ 6.2$ billion

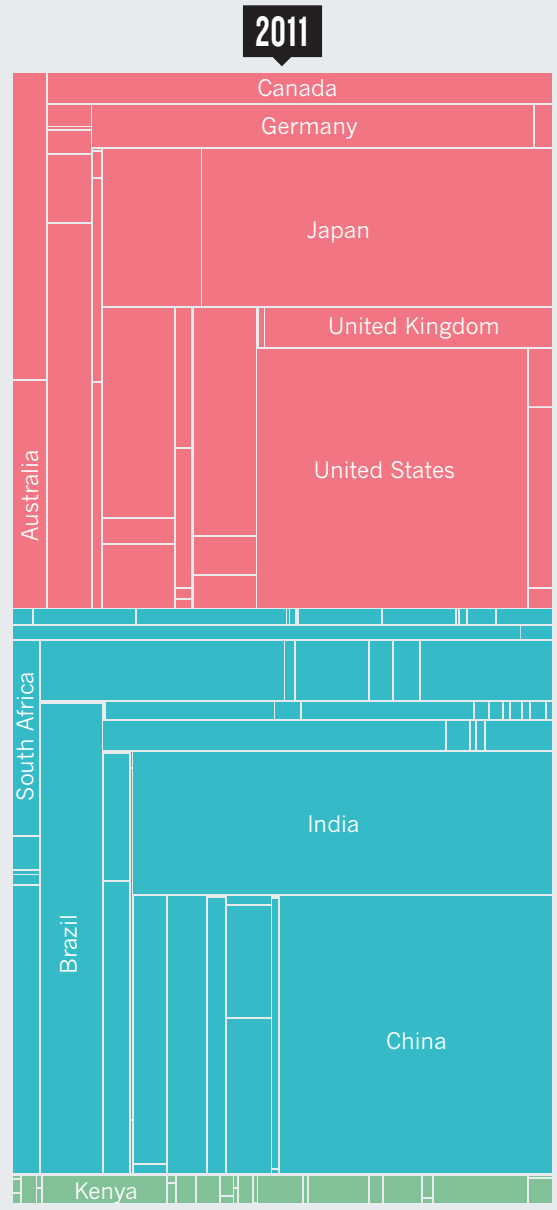

Total spend $\$ 38.1$ billion
INDUSTRY-LED

In both high- and middle-income countries, the share of AgR\&D by private companies is increasing relative to that pursued by universities and government agencies.

\section{N Public AgR\&D Private AgR\&D}

\section{0}

\section{1}

$$
\text { Proportion of world AgR\&D spending }
$$

\section{WORLDS APART}

The gap between poor and rich countries in per capita spending on public AgR\&D widened from 7.7-fold in 1980 to 11.7-fold in 2011.

1980 (1911

the midst of a historic transition (see 'Feeding the world'). For 2011, 5\% of world-

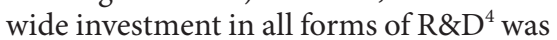
directed towards food and agriculture. These global gross domestic public and private expenditures on AgR\&D totalled US\$69.3 billion (in PPP dollars). Around $55 \%$ of this spending took place in highincome countries (as classified by the World Bank), down from $69 \%$ in 1980 . Meanwhile, middle-income countries (including China, Brazil and India) were responsible for $43 \%$ (their share was 29\% in 1980).

The shift in expenditures by universities and government agencies has been even more dramatic. Rich countries accounted for $56 \%$ of global public-sector spending on AgR\&D in 1960, but only 47\% in 2011. By this point, government spending in middleincome countries - $50 \%$ of global AgR\&D public-sector spending - had overtaken that in high-income countries.

What is driving this shake-up in the rank order of spenders?

It is complex. Decades of decline in the real price of food and a sense that food provision was a solved problem may have fostered complacency among policy-makers and politicians in those countries that had a leading role in $A g R \& D$ throughout most of the twentieth century ${ }^{4}$ - including the United States, the United Kingdom and Australia. Meanwhile, some middle-income countries have been ramping up their spending to feed their increasingly wealthy populations (in the case of China and India), or to push into export markets (Brazil).

In middle-income nations overall, public spending grew by nearly $6 \%$ per year between 2000 and 2011, compared with an average of nearly $4 \%$ per year during the previous four decades. In rich countries, public AgR\&D spending grew by just $0.8 \%$ between 2000 and 2011 (all figures are adjusted for inflation).

\section{INDUSTRY INVESTMENT}

Another major recent shift revealed by our data is in the balance between public- and private-sector contributions.

Historically, the bulk of research in food and agriculture was carried out by universities and government agencies. But in 2011, an average of $52.5 \%$ of the research on crop breeding, informatics, fertilizers, pesticides and food technologies in rich countries was being done by private firms (in 1980, the figure was $42 \%$ ). For middle-income countries, the private proportion of domestic spending was 37\% in 2011 (up from 19\% in 1980). Middle-income countries' share of private AgR\&D spending in 2011 was $35.5 \%$, up from close to $16 \%$ in 1980 .

The recent growth in investment in private AgR\&D in China is especially striking. In 2011, more than $\$ 6$ billion, or 
around 57\% of the country's entire domestic AgR\&D spending that year, came from the private sector. In China, the 'industrial enterprises' engaged in AgR\&D include state-owned organizations - such as the China National Agricultural Development Corporation and the China National Cereals, Oils and Foodstuffs Corporation, which now effectively operate as for-profit firms - as well as private companies such as the Yili Group in Hohhot, and the China Yurun Food Group in Nanjing.

The increasing importance of privatesector R\&D globally reflects two reinforcing developments. One is the impressive growth in R\&D in crop genetics, farm machinery, agricultural chemicals and food processing in at least some middle-income countries. The other is the offshoring of AgR\&D to rapidly growing middle-income countries by multinational firms headquartered in the rich countries. In recent years, firms that have opened R\&D facilities in China have included Nestlé (which has three locations), Syngenta, PepsiCo and General Mills.

Today, the influence of corporations on AgR\&D is vast. People tend to think of private-sector R\&D - for instance, that pursued by companies such as Monsanto, DuPont Pioneer and Syngenta - as being mainly focused on agricultural chemicals, crop breeding and machinery. Yet food and beverages - involving multinationals such as PepsiCo, Kraft Heinz and Nestlé — was the focus of $44 \%$ of the total rich-country private AgR\&D in 2011.

As countries become wealthier, people tend to eat out more and eat more processed and prepared foods $s^{5}$, and so returns on private-sector investments in food research are likely to be higher. Similar market opportunities open up for farm technologies such as improved seeds, fertilizers, herbicides and machinery as countries develop and farms typically consolidate and improve their physical access to urban markets.

\section{THE R\&D DIVIDE}

Although the positioning of the top investors in AgR\&D is shifting, little seems to have changed for those at the bottom. In fact, on a per capita basis, investment by low-income countries has shrunk considerably.

In 1980, for every dollar of AgR\&D spent in high-income countries, just 3.5 cents was spent in the low-income countries. Three decades on, this divide is roughly the same. But the gap has widened considerably when $\mathrm{AgR} \& \mathrm{D}$ spending is evaluated per capita. In 1980 , the rich countries invested $\$ 13.25$ per person in public AgR\&D, whereas the poor countries invested $\$ 1.73$ (a 7.7-fold difference). By 2011, this per capita spending gap had widened to an 11.7-fold difference: rich countries invested $\$ 17.73$ per person, poor countries invested just $\$ 1.51$.

The divide is even more pronounced for private-sector spending. In 2011, for every dollar of private AgR\&D spent in highincome countries, a meagre $0.8 \$$ was spent in low-income countries. Moreover, whereas private firms in rich countries spent $\$ 1.10$ for every public AgR\&D dollar in 2011, the comparable private investment in poor countries was $15 \phi$.

In short, those regions of the world that are experiencing the highest rates of population growth - the number of people living in sub-Saharan Africa has more than doubled since 1980 to 962 million today - are the places where per capita investment in AgR\&D is among the lowest in the world.

\section{A CHANGING WORLD}

One of the major global challenges in the years ahead is getting the relevant agricultural innovations into the hands of the world's poor farmers, such as those in south Asia and sub-Saharan Africa. Even with the rise of some middleincome countries, food and agricultural research continues to be concentrated in just a handful of nations. In 2011, the top 10 countries ranked by spending

\section{"Without sufficiently supported research and innovation in agriculture, crop yields are bound to decline."} on AgR\&D accounted for $70 \%$ of the total investment worldwide; the bottom 100 contributed just $9 \%$ of that year's total. Yet these 100 are home to $22 \%$ of the world's population.

More and sustained government funding will be essential, along with robust and agile institutional innovations that foster public and private investment in poor-country agriculture. Without efforts to improve the global spread and adaptation of locally relevant technologies, it is likely to get much harder for poor farmers to feed themselves, let alone their nations' increasingly urbanized populations.

In those countries currently responsible for most of the world's agricultural production, the innovation challenges are also pressing, if different. History has already shown the cost of running down investment on food and agricultural research in the face of everevolving pathogens. The emergence of new virulent strains of wheat stem rust in Uganda in the late 1990s and their subsequent spread throughout Kenya, Ethiopia, South Africa and elsewhere in Africa is a reminder of the need for continued scientific vigilance ${ }^{6}$. Years of success in keeping the disease at bay had left only a handful of researchers worldwide studying the pathogen.

Without sufficiently supported research and innovation in agriculture, crop yields are bound to decline as economic and environmental changes (including changes in weather patterns and crop pests and diseases driven in part by climate change) undermine past productivity gains.

Achieving even higher levels of productivity to feed a growing, increasingly wealthy and more urbanized population - while sustaining or rehabilitating fragile natural resources - is going to require considerably more investment in $\mathrm{AgR} \& \mathrm{D}$. It will also require both public and private investment, because the two tend to support different, often complementary, types of R\&D. The private sector is more attuned to market opportunities - and so well-suited to supply pesticides to farmers, for example. The public sector is better placed to investigate solutions to landscape-scale, longer-term challenges, such as the management of pesticide resistance.

If present trends continue, global AgR\&D in the middle of the twenty-first century will look very different from how it looked at the dawn of the century. The rise of AgR\&D in the rapidly growing middle-income countries, and the increase in private-sector participation in various regions are encouraging. But the retreat from public AgR\&D by rich countries and the continued comparatively low levels of investment in many poorer countries, are concerning. Rapidly regaining lost ground for these parts of the world is an obvious priority if we are to feed the world sustainably to 2050 and beyond.

Philip G. Pardey is a professor in applied economics and director, and Connie Chan-Kang is a research associate at the International Science and Technology Practice and Policy Center, University of Minnesota, St Paul, Minnesota, USA. Steven P. Dehmer is research investigator and health economist at the HealthPartners Institute, Minneapolis, Minnesota, USA. Jason M. Beddow died suddenly in April 2016 as this Comment was being finalized for submission.

e-mail:ppardey@umn.edu

1. Pardey, P. G., Chan-Kang, C., Beddow, J. M. \& Dehmer, S. M. Documentation — InSTePP International Innovation Accounts: Research and Development Spending, version 3.5 (Food and Agricultural R\&D Ser.) (InSTePP Center, 2016); available at http://go.nature.com/2cc9t4b

2. Alston, J. et al. Persistence Pays: U.S. Agricultural Productivity Growth and the Benefits from Public R\&D Spending (Springer, 2010).

3. Hurley, T., Rao, X. \& Pardey, P. G. Am. J. Agric Econ. 96, 1492-1504 (2014).

4. Pardey, P. G., Chan-Kang, C., Beddow, J. M. \& Dehmer, S. P. Am. J. Agric. Econ. 97, 1312-1323 (2015).

5. Fabiosa, J. F. in The Oxford Handbook of the Economics of Food Consumption and Policy (eds Lusk, J., Roosen, J. \& Shogren, J.) Ch. 23 (Oxford Univ. Press, 2012).

6. Pardey, P. G. et al. Science 340, 147-148 (2013).

Supplementary information accompanies this article online: see go.nature.com/2cfvkij 